\title{
An Experimental Study of Airfoil Icing Characteristics
}

Robert J. Shaw, Ray G. Sotos, and Frank R. Solano Lewis Research Center Cleveland, Ohio

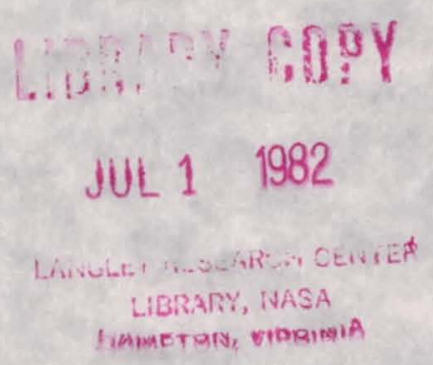

Prepared for the

Twentieth Aerospace Sciences Conference sponsored by the American Institute of Aeronautics and Astronautics

Orlando, Florida, January 11-14, 1982 


\section{AN EXPERIMENTAL STUDY OF AIRFOIL ICING CHARACTERISTICS}

Robert J. Shaw, Ray G. Sotos, and Frank R. Solano

National Aeronautics and Space Administration

Lewis Research Center

Cleveland, Ohio 44135

Introduction

Current understanding of airfoil ice accretion characteristics and resultant decrease in aerodynamic performance (primarily decreased $\mathrm{C}_{1 \max }$ and increased $C_{d}$ ) relies upon experimental tests in an icing simulation facility. The majority of the experimental information presently available was gathered by NACA researchers in the NASA Icing Research Tunnel during the 1940-1960 time period (ref. 1-4) and emphasized airfoil sections of interest at that time. The airfoils tested were primarily intended for military and commercial transport applications.

The current NASA aircraft icing research effort is primarily concerned with rotorcraft and general aviation sensitivity to icing encounters. The airfoil sections used by these classes of vehicles can be significantly different than those previously studied with regard to sensitivity to icing. Also, computer based airfoil design codes are currently being used to design airfoil geometries for specialized applications (ref. 5). The icing sensitivities of such airfoil geometries which have been optimized to provide high levels of aerodynamic performance are not currently known.

Using the data acquired by NACA, Gray (ref. 6) correlated the experimental airfoil aerodynamic performance data to determine relationships for changes in airfoil lift, drag, and pitching moments due to ice accretions. An attempt was made to generalize the results by including in the correlations terms which were a function of the airfoil leading edge radius. 
These correlations are currently being used (e.g., ref. 7) to estimate airfoil performance degradations due to icing encounters. However, it is not known whether these correlations apply to all classes of airfoil designs or just to more limited classes. Also the range of environmental conditions (LWC, $\bar{d}$ ) for which the correlations apply has not been investigated.

The current NASA Icing Research effort involves testing airfoils that are representative of current as well as possible future generation designs to measure ice accretion characteristics and resultant aerodynamic performance degradation. The measured aerodynamic performance will be compared with the previously developed performance correlations to test their general applicability.

NASA is also sponsoring the development of computer based methodologies to predict the ice accretion characteristics and resultant aerodynamic performance degradation of airfoils subjected to an icing environment (e.g., ref. 8). Data gathered from experimental airfoil icing programs will serve as test cases to determine the accuracy and limitations of such computer based methodologies.

Once the analysis procedures have been developed and experimentally verified, preliminary studies of the sensitivity of proposed airfoil designs can be accomplished using the computer codes rather than in an icing simulation facility. 
The experimental tests discussed in this paper concerned the icing characteristics of a general aviation wing section. The wing section had a NACA $632^{-A 415}$ airfoil which is representative of current general aviation aircraft sections.

Selected results from the icing wind tunnel tests of this wing section will be presented and discussed in the following sections. 
Nomenclature

Cd

Wing section drag coefficient.

Cdice, frost

Wing section drag coefficient with primary ice accretion and aft frost layer.

Cdice, no frost

Wing section drag coefficient with primary ice accretion but aft frost layer removed.

$\mathrm{C}_{\text {Imax }}$

Wing section maximum lift coefficient.

C

Wing chord, m

$\bar{d}$

Volume median water droplet diameter, microns.

H

Icing Research Tunnel width, 2.74m (9 feet).

k Wing section upper surface ice height, $\mathrm{m}$.

LWC Icing cloud liquid water content, $\mathrm{gm} / \mathrm{m}^{3}$.

rle Airfoil leading edge radius, percent chord. 
$T_{\text {too }}$

$t_{\text {ice }}$

V

$v_{\text {oo }}$

$x$

Y

y

$\alpha$

$\Delta \mathrm{C}_{\mathrm{NACA}}$

$\Delta c_{d}$

$\Delta c_{1_{\max }}$
Wind tunnel total temperature, ${ }^{\circ} \mathrm{C}$.

Icing encounter time, min.

Velocity, $\mathrm{m} / \mathrm{sec}$.

Freestream velocity, $\mathrm{m} / \mathrm{sec}$.

Airfoil axial coordinate, $m$.

wing section wake lateral coordinate, $\mathrm{m}$.

Airfoil normal coordinate, $m$.

Wing section angle-of-attack in wind tunnel

measurement plane, degrees

Change in drag coefficient due to icing predicted by NACA correlation.

Change in drag coefficient due to icing measured during wind tunnel test.

Change in maximum lift coefficient due to ice accretion. 


\section{Apparatus and Procedure}

\section{Test Model}

The test model used in the experimental program was a section of a wing taken from a general aviation aircraft. The model had a movable wing flap which was fixed in the cruise position for these tests.

The airfoil coordinates of the NACA $63_{2}$-A415 wing section are given in figure 1. The model chord was $1.34 \mathrm{~m}$ ( 52.8 inches). The wing section had a geometric twist of approximately .43 degree/ meter of span (.13 degree/ft.).

\section{Experimental Facility}

The wing section ice accretion studies were conducted in the Icing Research Tunnel (IRT) of the NASA Lewis Research Center. The IRT is a closed cycle, atmospheric total pressure wind tunnel with a test section 1.83 meters (6 feet) high and 2.74 meters ( 9 feet) wide. A schematic of the tunnel is shown in figure 2. The maximum tunnel test section speed is $134 \mathrm{~m} / \mathrm{sec}$ ( 300 mph) with no model installed. 
The atmospheric icing cloud is simulated by spraying water into the airstream slightly upstream of the contraction section. Water is injected into the airstream by 77 air-atmoized, heated water spray nozzles located on six horizontal spray struts. The nozzle water and air are heated to $355^{\circ} \mathrm{K}$ $\left(640^{\circ} \mathrm{R}\right)$. The nozzle pattern was previously selected to maximize the cross sectional area of uniform cloud properties existing at the tunnel test section.

The liquid water content can be varied from approximately 0.5 to over $2.0 \mathrm{gm} / \mathrm{m}^{3}$ with volume median droplet diameters of 11 to 20 microns. The water droplet diameter distributions are approximately Langmuir D.

The tunnel airstream temperature can be regulated by the 2100 ton cooler indicated in figure 2 . The tunnel total temperature can be maintained as low as $-29^{\circ} \mathrm{C}\left(-20^{\circ} \mathrm{F}\right)$ and is measured by three thermocouples located on cross bars attached to the turning vanes upstream of the water spray bars. The theromocouples sense the total temperature in the top, middle, and bottom portions of the airstream. Attention is given during the test runs to maintaining the uniformity of the total temperture profile. Total temperature values quoted in this paper represent the average of the three individual measurements.

The wing section was mounted vertically in the IRT test section as shown in figure 3 . Model angle-of-attack was varied by rotating the tunnel 
turntable to which the model was affixed. For this paper, the angles-ofattack auoted represent the section value in the IRT centerline plane (indicated by the horizontal marking on the model pictured in figure 3 ). The centerline angle-of-attack differed from the floor angle-of-attack for the wing section by the model geometric twist ( 0.4 degree).

Test Instrumentation/Data Acquisition

Accreted ice shapes and resultant section drag coefficients were measured during the test program. Accreted ice shapes were determined by one of two techniques depending on the time of the icing encounter (or equivalently) the mass of the accreted ice.

For short time icing encounters, generally less than 5 minutes, tracings were made of the actual ice shapes. A steam scrapper was used to remove a small section of the ice accretion in the immediate vicinity of the centerline plane. A template which fit the leading edge contour was then inserted into the gap, and a tracing of the ice shape was made.

For the longer duration icing encounters, a sufficient ice accretion existed to allow a piece to be removed without destroying the ice shape characteristics. A section of the ice accretion (approximately one-third meter long) was removed from the wing model by spraying steam inside the wing adjacent to the leading edge. Once the piece of ice was removed from the model, it was dipped into a container of liauid beeswax, and the beeswax 
quickly solidified around the ice. After the ice had melted, a small hole was drilled in the beeswax mold, and the water was drained out. The mold was then filled with plaster which was allowed to harden. Next, the mold was melted leaving a plaster casting of the original ice accretion shape. The plaster castings were then available for comparison with the tracings which were also made.

The ice accretion shapes shown in this paper were those made by the tracing method.

The section drag of the wing model in the centerline plane was determined using a conventional drag wake survey probe. The probe can be seen positioned behind the NACA $63{ }_{2}-A 415$ wing section model in figure 3 . Figure 4 shows a closeup view of the probe itself.

A differential pressure transducer measured the difference between the local total and static pressure levels as determined by the wake survey probe as it continuously traversed the wing wake. The pressure transducer was located outside the IRT test section to shield it from the extreme temperature environments existing in the tunnel airstream.

The traverse speed of the wake survey probe was adjusted before the actual test so that no lags in prohe response existed. 
The probe was calibrated in an instrument calibration facility at NASA Lewis and found to have a maximum error in indicated velocity of 0.7 percent over the range of $15-137 \mathrm{~m} / \mathrm{sec} .(50-450 \mathrm{ft} / \mathrm{sec})$. Thus no calibration factor was applied to the measured velocity levels.

As the probe traversed the wake, the instantaneous analog signal from the differential pressure transducer was fed into an analog module along with a similar analog signal from a separate differential pressure transducer coupled to the IRT test section pitot-static probe. From these inputs the module computed the velocity ratio $\left(\mathrm{V} / \mathrm{V}_{\mathrm{oo}}\right)$ and output an analog signal of $\mathrm{V} / \mathrm{V}_{\mathrm{Oo}}$

The analog signal of $\mathrm{V} / \mathrm{Voo}$ and an analog signal representing the wake survey probe position were continuously digitized by an $A / D$ convertor, and the digital information was passed on to the NASA Lewis central computing facility. The section drag coefficient was calculated using the digital data and the following relation:

$$
C_{d}=\frac{2}{C} \int \frac{V}{V_{\infty \circ}} \frac{\left(1-\frac{V}{V}\right)}{V_{\infty \circ}} d Y
$$

Before the integration was performed nowever, an adjustment to the values of the velocity ratio $V / V_{0 o}$ was performed to account for: (1) wake survey probe blockage effects and (2) wing model blockage effects. 
As figures 3 and 4 indicate, the traversing mechanism for the wake survey probe introduced a finite wind tunnel blockage. Tunnel velocity measurements with no model present, indicated the blockage due to the wake survey probe was approximately four percent and independent of tunnel test section speed $\left(\mathrm{V} / \mathrm{V}_{\mathrm{OO}}=1.04\right)$.

Also the model tested was rather large relative to the IRT test section dimensions ( $\mathrm{C} / \mathrm{H}=.49$ for the $\mathrm{NACA} 632^{-\mathrm{A} 415}$ model), and hence it presented a large blockage to the tunnel flow, especially at the higher angles-of-attack. Velocity levels approaching $1.10\left(\mathrm{~V} / \mathrm{V}_{\mathrm{oo}}\right)$ were measured outside the wake for the model for angles-of-attack of eight degrees and higher. In addition, the wake survey probe tip was located less than one chord length downstream of the trailing edge of the model (.7c for the NACA $632^{-A 415}$ model). Thus as the model angle-of-attack was increased, the static pressure measured by the survey probe deviated from the freestream static pressure level by increasing amounts.

However, since the individual total and static pressure levels in the wake and freestream were not measured, drag coefficient relations such as those developed by Jones (ref. 9) which account for differences between wake and freestream static pressure levels could not be employed. The following approximate procedure was used to account for the blockage effects:

(1) The original wake survey velocity profile was examined to determine the endpoints of the viscous wake. 
(2) The values of the velocity ratio $\left(V / V_{00}\right)$ for the two wake endpoints were compared, and the larger value was used to calculate a velocity ratio correction factor by subtracting 1.0 from this value.

(3) All velocity ratio values contained within the viscous wake were adjusted by subtracting the velocity ratio correction factor prior to computing the section drag coefficient according to equation 1 .

While this simplified procedure for accounting for the blockage error is only approximate, estimates made indicate the resulting drag coefficient levels will be underestimated by about .0005 to .0015.

Drag wake surveys were taken only when the IRT icing spray was turned off. While the spray system was on, the probe was retracted behind a protection wind screen to prevent ice from being accreted on the probe tip. The anti-iced wind screen can be seen in figures 3 and 4 . Figure 4 also shows a Copper tube running along the leading edge of the probe support. Steam was passed through this tube to anti-ice the support strut.

Since the IRT currently has no force balance system, no direct measurement of wing section lift could be made. However, the model was "instrumented" with tufts on the suction surface to enable a qualitative determination to be made of the boundary layer characteristics and particularly the section stall angle. 
Test Matrix/Test Procedure

The matrix of test conditions chosen for the wing section is presented in Table I. The combination of low velocity, high angle-of-attack corresponds to a representative aircraft climb condition while the high velocity, low angle-of-attack combination corresponds to a representative aircraft cruise condition.

The liquid water content (LWC) values that correspond to volume median droplet diameters of 15 microns were chosen to be representative values within the IRT operational envelope for the given freestream velocity level. The liquid water contents corresponding to the 20 micron volume median droplet diameters were the maximum levels available from the IRT icing spray system for the particular freestream velocity level.

Two IRT total temperature levels were chosen for the tests. The $-4^{\circ} \mathrm{C}$ $\left(25^{\circ} \mathrm{F}\right.$ ) level was chosen to result in glaze ice growths; while the $-26^{\circ} \mathrm{C}$ $\left(-15^{\mathrm{O}} \mathrm{F}\right)$ level was chosen to result in rime growths.

The nominal icing spray times chosen were $2,5,10,15$, and 20 minutes. The general test procedure followed during the test program was:

1. The model angle-of-attack was set.

2. The desired wind tunnel conditions $\left(V_{00}, T_{t o o}\right)$ were established. 
3. The wind tunnel spray system was turned on to establish the required icing cloud conditions ( $L W C, \bar{d}$ ).

4. After the required icing encounter time had elapsed, the icing cloud spray system was turned off.

5. The drag wake survey profile was recorded.

6. For selected test conditions, the model angle-of-attack was changed, and the resulting drag wake survey profile was recorded. The model angle-of-attack was increased and the resulting drag wake survey profiles recorded until an angle-of-attack was found for which the tufts indicated a significant upper surface stall zone existed.

7. The wind tunnel was brought to idle and the accreted ice shape was measured by one or both of the techniques already discussed.

\section{Results and Discussion}

Figure 5 presents the experimental clean wing section drag coefficient variation with angle-of-attack for the wing section models tested. The values of drag coefficient and angle-of-attack presented are not corrected for wind tunnel wall effects. This approach was taken because no measurements of section lift coefficient characteristics were made, and the value of lift coefficient is needed if commonly used wall correction formulae are to be applied. 
The onset of trailing edge separation is also indicated on the figure. The angle at which trailing edge separation first occurred was determined by watching a chordwise row of tufts placed $.08 \mathrm{~m}$ ( 3 inches) below the centerline. The aft most tuft was located at the 96 percent axial station.

Figure 6 presents results typical of those observed during the test program for the increase in wing section drag coefficient with icing spray time for rime and glaze icing conditions. Data is presented for cruise operating conditions and an icing cloud liquid water content of $1.5 \mathrm{gm} / \mathrm{m}^{3}$ with a volume median droplet diameter of 15 microns.

The data is shown plotted in the form of increase in drag coefficient over the corresponding clean (non iced) wing section level, as given by figure 5. This form of presenting the drag coefficient data is the same as that used by previous NACA investigators (e.g., ref. 1-3).

For each icing spray time shown in the figure, two values of wing section drag coefficient are shown. The npen symbols represent the section drag coefficient measured by the wake survey probe immediately after the icing spray cloud had been turned off. The solid symbols represent the drag coefficient level measured after the frost layer which had accumulated on the model aft of the primary ice accretion was removed. This frost layer was removed by bringing the wind tunnel to an idle condition, entering the test section, and wiping the model with rags, taking care not to disturb the primary ice accretion. 
Figure 6 indicates the aft frost layer made a significant contribution to the drag for both the rime and glaze icing encounters. For example for the 20 minute glaze icing encounter, the primary ice accretion caused a drag coefficient increase of about 130 percent over the nominal clean wing section level, but the presence of the aft frost layer resulted in a drag coefficient increase of about 240 percent. For the 15 minute rime icing encounter, the primary ice accretion increased the drag coefficient level by about 40 percent over the corresponding clean wing section value while the combination of primary ice accretion and aft frost layer increased the drag coefficient by about 140 percent.

Previous investigations (refs. 1 and 10) have identified the aft frost growths on wing models as being one significant difference between icing wind tunnels and natural icing encounters. The aft frost growths observed on icing wind tunnel models is attributed to the increased turbulence level present in the tunnel airstream due to the spray bar induced disturbances and a supersaturation effect present in the tunnel airstream.

These aft frost growths are as a rule not observed for natural icing encounters (ref. 10). However, reference 2 does indicate that primary ice accretions as well as aft frost growths may occur in flight during a change from cold to warmer, more humid icing conditions. Thus care must be exercised in interpreting icing wind tunnel results both with regard to limits of impingement and aerodynamic performance penalties due to icing encounters. As figure 6 indicates, if the importance of the aft frost layer is not 
appreciated, the aerodynamic performance penalties for a given wing section measured in an icing wind tunnel can be significantly different than the penalties that would be observed for a natural icing encounter with the same environmental conditions.

The increases in wing section drag coefficient level due to the aft frost layer growths for the matrix of test conditions investigated are shown in figure 7. Generally speaking the effect of the aft frost layer appears to have been greater for the rime ice growth conditions that it was for the glaze ice growth configurations. However, the effect for the glaze ice conditions increased with icing encounter time while it was relatively constant for the rime ice conditions. The reason for the difference in importance of the aft frost growth for rime versus glaze icing conditions is not known. However, it is most likely due to the effect of the primary ice accretion on the development of the wing suction and pressure surface boundary layers and the subsequent interaction of these boundary layers with the aft frost layer which acts like a distributed surface roughness.

Also, the analog traces presented in figure 8 which are typical of those measured during the test program indicate that the aft frost layer affected the suction and pressure side boundary layers differently for the rime and glaze icing conditions. Removal of the aft frost layer for the rime icing encounter lessened the resulting wake deficit for both the pressure and suction sides; however, no such improvement was observed for the pressure side wake deficit for the glaze icing encounter when the aft frost growth was removed. 
Future drag coefficient levels presented in this paper will represent values measured after the aft frost layer was removed.

Figure 9 presents the increase in wing section drag coefficient with icing spray time for rime and glaze icing conditions and cruise operating conditions with the corresponding ice accretion shapes also shown. For the glaze icing conditions, the distinct double horn accretion formed after ten minutes and the horns continued to grow in size with time. As expected, the rime ice accretion grew in a much more streamlined fashion and upstream to the local flow direction.

As figure 9 indicates, the drag increase was significantly greater for the glaze ice accretions than for the rime ice accretions especially for icing spray times greater than five minutes.

Previous wing icing studies (e.g., ref. 1-3) have indicated that the primary cause of the drag increases observed for glaze icing conditions is the upper surface horn which acts like a flow spoiler causing an upper surface boundary layer separation. The analog traces of the measured wake velocity profiles shown in figure 8 indicate that for the glaze icing conditions, a majority of the increased deficit observed in the wake did occur on the suction side. However, for the rime icing conditions, an increased wake deficit occurred on both the suction and the pressure sides. 
Figure 10 presents the variation in drag coefficient increase with icing spray time for glaze and rime icing conditions and climb operating conditions. The corresponding ice accretion shapes are also shown. The increase in drag coefficient with time was very similar for both the rime and glaze icing conditions. For example, for a 15 minute icing spray, a 40 percent increase in drag was measured for both rime and glaze icing conditions.

The glaze ice accretion shapes developed a characteristic double horn configuration after ten minutes of icing spray time while the rime accretions were more streamlined. As expected, these characteristics were similar to those alredy noted for the accretion shapes presented for the cruise conditions (figure 9). However, the accretion shapes for the climb conditions were displaced toward the pressure side of the wing section when compared to the corresponding shapes for the cruise conditions. This occurrence indicates the effect of changes in angle-of-attack and freestream velocity on the water droplet local collection efficiency distribution for the NACA 63 -A415 wing section.

Figure 11 indicates the NACA $632^{-A 415}$ wing section was more sensitive to the glaze ice accretions for cruise operating conditions than for glaze ice accretions for climb operating conditions. The differences became more noticeable for icing spray times in excess of ten minutes. For the cruise conditions, the drag generally increased with increased icing spray time although a slight decrease was noted for the 15 minute icing spray. However, the drag increase appeared to level off for the climb conditions for icing spray time in excess of ten minutes. 
Comparing the two families of ice accretion shapes shown, it can be seen that while both exhibited double horn features for the longer duration icing sprays, the location (relative to the clean wing surface) and the height of the upper surface horns differed between the cruise and climb conditions for corresponding icing spray times. Evidently the upper surface horn for the cruise conditions had a greater impact on the development of the wing suction surface boundary layer than did the upper surface horn for the climb conditions.

Figure 12 compares the drag increase with icing spray time for rime icing conditions and cruise and climb operating conditions. The figure indicates the rime ice accretion shapes for both cruise and climb had similar effects on the development of the wing suction and pressure side boundary layers in that the drag increases for any given icing spray time were approximately equal.

Both families of rime ice accretion shapes were reasonably streamlined, expecially when compared with the glaze ice shapes (figure 11). Also, the location of the rime ice growths with regard to the wing surface was apparently not an important factor in the resulting wing performance. That is, although the rime ice growths for climh were displaced toward the pressure surface, the resulting drag increase was approximately the same as for the corresponding cruise case. This is in direct contrast to the apparent importance of the location and size of the uppper surface horns of the glaze ice accretions on the resulting drag increase (figure 11) which has already been noted. 
Selected drag polars for the NACA $63{ }_{2}$-A415 wing section are presented in figure 13 for 15 minute glaze and rime icing encounters corresponding to cruise and climb conditions.

The increase in drag with angle-of-attack was most pronounced for the glaze ice accretion for cruise although the glaze ice accretion for climb and the rime ice accretion for cruise also caused significant drag increases with increased angle-of-attack. These three drag polars suggest that the aerodynamic performance of the NACA $63{ }_{2}-$ A415 wing section was significantly reduced by the respective ice accretion shapes. However, the drag polar for the rime ice accretion for climb showed little variation with angle-ofattack. As shown on the figure, the rime ice accretion for climb was somewhat streamlined and evidently it had less of an influence on the development of the wing boundary layers, especially at the higher angles-of-attck.

As previously indicated, the IRT currently has no force balance capability so it was not possible to measure the reduction in wing section lift coefficient due to the various ice accretions. However the experimental correlation developed by Brumby (ref. 11) for the reduction in $\mathrm{C}_{\text {lmax }}$ due to surface roughness was used to estimate the reduction in $C_{1 \max }$ due to the various glaze ice accretions for the NACA $63{ }_{2}$-A415 wing section model.

Brumby correlated the reduction in $C_{I_{\max }}$ for a number of airfoil geometries for a number of different types of surface roughness (including frost and ice) and found that the reduction in $c_{1 \max }$ correlated with the location of the roughness element $(x / c)$ and the characteristic height of the element $(k / c)$. 
For roughness elements located at the wing leading edge, Brumby's correlation could be given by the following equation:

$$
\Delta C_{1 \max }=14.4 \log _{10}(\mathrm{k} / \mathrm{c})+64.6
$$

Equation (2) was used along with the experimentally measured ice accretion shapes to estimate the reductions in $C_{\text {lmax }}$ for the various glaze icing encounters for the NACA $632^{-A 415}$ wing section model. The results indicated reductions in $C_{\text {lmax }}$ of 30 to 40 percent might be expected. Certainly these are rather large reductions in $C_{\text {lmax }}$, but the values are comparable in magnitude to reductions in $C_{1 \text { max }}$ measured on a NACA $65_{2}-A 215$ wing section with various artificial ice shapes attached to the leading edge (ref. 12). If the predicted levels of $C_{\text {Imax }}$ are reasonably accurate, then the effect of the glaze ice accretions on the handling characteristics of general aviation aircraft with such a wing section would be significantly affected.

The data presented in this paper indicate the rime and glaze ice accretion shapes had a significant influence on the overall aerodynamic performance of the NACA $63{ }_{2}$-A415 wing section and thus on the development of the suction and pressure surface boundary layers. Indeed the adverse effects of ice accretions on wing aerodynamic performance has been known for a long time (e.g., refs. 1-4); however, the details of houndary layer development over a wing with such irregular shapes on the leading edge are still largely unknown. 
The chordwise row of tufts placed on the suction surface of the NACA ${ }^{63} 2^{-A 415}$ wing did give some qualitative indication of the effect of the upper surface glaze ice horn on the suction surface boundary layer development. The tufts located downstream of the glaze ice accretions but upstream of the wing maximum thickness location showed no indication of large scale flow separation being present. That is the tufts indicated the separation zone was confined to the wing leading edge region and boundary layer reattachment occurred just downstream of the primary ice accretion. The reattached boundary layer profile was apparently highly distorted and deenergized to result in the observed levels of drag increase.

A better understanding of the fundamental fluid mechanical aspects of the boundary layer development can only be gotten from future experiments dedicated to measuring fundamental flow field characteristics such as surface static pressure distributions and boundary layer profiles. Admittedly the need to measure such flowfield characteristics in an icing environment presents some demanding instrumentation requirements. However, the knowledge gained from such programs would greatly aid in interpreting future icing wind tunnel test results of wing icing sensitivity studies. Also, the information would be invaluable to those individuals developing and verifying computer codes for predicting aerodynamic performance degradations due to icing encounters. 
As already indicated, the only airfoil aerodynamic performance degradation correlations which are available in the open literature are those developed by NACA (ref. 6). The correlations were based primarily upon icing data gathered for an unswept NACA 65A004 airfoil but were later generalized using limited data gathered for other thicker airfoil sections (NACA O011, NACA 63A009, NACA65 -212, and NACA 63,-015 airfoils).

Figure 14 presents a comparison of the measured increases in drag coefficient for the NACA $63{ }_{2}$-A415 wing section tested with the levels predicted by the drag coefficient correlation expression given in reference 6 . As the figure shows, there was considerable scatter in the comparisons with only a very few experimental measurements of $\Delta c_{d}$ being in close agreement with the predicted values. In general, the experimental drag coefficient increases for the NACA $632^{-A 415}$ wing section were somewhat less than the corresponding calculated values.

For comparison, figure 14 also shows the relative spread in the agreement of the NACA drag correlation for the original airfoil data upon which the correlation was based. The data acquired for the NACA $632-A 415$ wing section generally falls within the scatter band of the original NACA data.

However, figure 14 also indicates that the comparison was much worse for the high liquid water content data. In general, for the high liquid water content data, the measured increases in drag were less than half the corresponding predicted increases. The NACA correlations were developed primarily 
upon data of tests conducted with liquid water contents in the range of 0.4 to $1.4 \mathrm{gm} / \mathrm{m}^{3}$. These results suggest that the NACA performance degradation correlations may have a limited range of liquid water content for which reasonable predictions may be expected.

The form of the drag correlation developed by NACA was strongly influenced by the performance characteristics of the NACA $65 A 004$ airfoil, a thin airfoil section ( 4 percent maximum thickness) with a very small leading edge radius ( 0.1 percent of chord).

The NACA 65 A004 airfoil section exhibited a suction surface boundary layer separation for angles-of-attack greater than about four degrees with no ice accretion present (ref. 1). As reference 1 indicated, certain ice accretions acted as a "nose flap" and effectively added camber to the NACA 65A004 section which actually improved the aerodynamic performance of the iced airfoil, especially for higher angles-of-attack. As such the aerodynamic performance degradation correlations developed have this information built into them. Thicker airfoil sections such as the NACA $63{ }_{2}$-A415 section with increased leading edge radii and improved high angle-of-attack performance would not be expected to exhibit any increased performance due to accreted ice.

Also the NACA drag correlation was based upon the characterization of the accreted ice shapes by an upper surface horn height and the angle of this upper surface ice protuberance witn respect to the chord line. The measured 
accretions for the NACA 65 A004 wing section presented in reference 1 do appear to lend themselves to being described by these two variables. However, the ice accretion shapes measured for the NACA $632^{-A 415}$ wing section (e.g., figures 9 and 10) appear to be more difficult to adequately characterize by only the height and angle variables. The data presented in this paper suggest that the wing surface location of the upper surface horn protuberance is also important in determining the resulting aerodynamic penalties incurred. This is in agreement with the correlations presented by Brumby (ref. 12) which showed a strong influence of the roughness location as well as roughness height on the resulting decrease in $\mathrm{C}_{\text {lmax }}$.

In addition, the NACA correlations are most appropriate for longer duration icing encounters where the ice accretion has had ample time to develop its governing characteristics. For the NACA $63{ }_{2}^{-A 415}$ wing section the data presented suggests at least 5 to 10 minutes of icing encounter time was required. For shorter duration icing encounters, the accretions, whether rime or glaze, might be better characterized as being like a distributed surface roughness, and correlations based upon such a formulation might be more appropriate. 
Summary of Results

A full scale general aviation wing with a NACA $63_{2}$-A415 airfoil section was tested in the NASA Lewis Icing Research Tunnel to determine the icing and resultant aerodynamic performance characteristics for representative rime and glaze icing conditions for cruise and climb aerodynamic conditions. Measurements were made of ice accretion shapes and resultant wing section drag coefficient levels.

The major results of the study can be summarized as follows:

1. Drag coefficient increases of about $\mathbf{1 3 0}$ percent were measured for a 20 minute glaze icing encounter and cruise aerodynamic conditions. The drag increased by about 40 percent for a 15 minute rime icing encounter and the same aerodynamic conditions.

2. The NACA $632^{-A 415}$ wing section was found to be less sensitive to rime and glaze ice accretions occurring for the climb aerodynamic conditions.

3. The observed aft frost layer growths contributed significantly to the measured increase in section drag coefficient level. 
4. Comparisons of measured increases in section drag coefficient due to the primary ice accretion with predictions of NACA drag correlation indicated agreement was as good as that for the original data upon which the correlation was based. Agreement was less satisfactory for the higher liquid water content cases compared.

\section{$\underline{\text { References }}$}

1. Gray, V. H. and Von Glahn, U. H., "Aerodynamic Effects Caused by Icing of an Unswept NACA 65A004 Airfoil," NACA TN 4155, 1958.

2. Gray, V. H. and Von Glahn, U. H., "Effect of Ice and Frost Formations on Drag of NACA $65_{1}-212$ Airfoil for Various Modes of Thermal Ice Protection," NACA TN 2962, 1953.

3. Von Glahn, U. H. and Gray, V. H., "Effect of Ice Formations on Section Drag of Swept NACA 63A-009 Airfoil with Partial-Span Leading Edge Slat for Various Modes of Thermal Ice Protection," NACA RME53J30, 1954.

4. Bowden, D. T., "Effect of Pneumatic De-Icers and Ice Formations on Aerodynamic Characteristics of an Airfoil," NACA TN 3564, 1956.

5. Szelazek, C. A. and Hicks, R. M., "Upper-Surface Modifications for $C_{1 \text { max }}$ Improvement of Selected NACA 6-Series Airfoils," NASA TM-78603, 1979. 
6. Gray, V. H., "Prediction of Aerodynamic Penalties Caused by Ice Formations on Various Airfoils," NASA TN D-2166, 1964.

7. Jackson, G. C., "AEROICE: A Computer Program to Evaluate the Aerodynamic Penalties Due to Icing," AFFDL-TM-79-9l-WE, Oct. 1979.

8. Bragg, M. B., Gregorek, G. M., and Shaw, R. J., "An Analytical Approach to Airfoil Icing," AIAA Paper 81-0403, Jan. 1981.

9. Schlichting, H., Boundary-Layer Theory, Sixth Edition, McGraw-Hill, New York, 1968, pp. 708-714.

10. Fraser, D., "Icing Experiments in Flight and Comparisons with wind Tunnel Testing," Advisory Group for Aeronautical Research and Development, North Atlantic Treaty Organization, Fifth General Assembly, Ottawa, Canada, June 1955.

11. Brumby, R. E., "Wing Surface Roughness: Cause and Effect," DC Flight Approach, No. 32, Jan. 1979, pp. 2-7.

12. Ingelman - Sundberg, M., Trunov, O. K., and Ivaniko, A., "Methods for Prediction of the Influence of Ice on Aircraft Flying Characteristics," Swedish - Soviet Working Group on Flight Safety, 6th Meeting, 1977, Item 2.2 (Report No. JR-1). 
TABLE I - - ICING TEST CONDITIONS

\begin{tabular}{|c|c|c|c|c|c|}
\hline & $V_{\infty}$ & $\alpha$ & $T t_{\infty}$ & LWC & $\overline{\mathrm{d}}$ \\
\hline Cruise & $\begin{array}{l}51 \mathrm{~m} / \mathrm{sec}(115 \mathrm{mph}) \\
51 \\
51\end{array}$ & $\begin{array}{l}2.6^{\circ} \\
2.6^{\circ} \\
2.6^{\circ}\end{array}$ & $\begin{array}{l}-4^{\circ} \mathrm{C}\left(25^{\circ} \mathrm{F}\right) \\
-4^{\circ} \mathrm{C} \\
-26^{\circ} \mathrm{C}\left(15^{\circ} \mathrm{F}\right)\end{array}$ & $\begin{array}{l}1.5 \mathrm{gm} / \mathrm{m}^{3} \\
2.34 \\
1.5\end{array}$ & $\begin{array}{l}15 \mu \\
20 \\
15\end{array}$ \\
\hline Climb & $\begin{array}{l}40 \mathrm{~m} / \mathrm{sec}(90 \mathrm{mph}) \\
40 \\
40\end{array}$ & $\begin{array}{l}6.6^{\circ} \\
6.6^{\circ} \\
6.6^{\circ}\end{array}$ & $\begin{array}{l}-4^{\circ} \mathrm{C} \\
-4^{\circ} \mathrm{C} \\
-26^{\circ} \mathrm{C}\left(\begin{array}{lll}-15^{\circ} & \mathrm{F}\end{array}\right)\end{array}$ & $\begin{array}{l}1.5 \\
2.9 \\
1.5\end{array}$ & $\begin{array}{l}15 \\
20 \\
15\end{array}$ \\
\hline
\end{tabular}




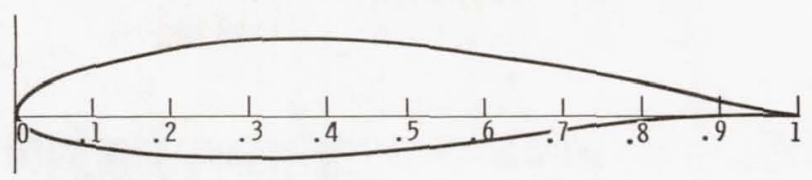

\begin{tabular}{|c|c|c|c|}
\hline \multicolumn{2}{|c|}{ UPPER SURFACE } & \multicolumn{2}{|c|}{ LOWER SURFACE } \\
\hline$\underline{x}$ & y & $\underline{x}$ & $\underline{y}$ \\
\hline $\bar{c}$ & c & $\bar{c}$ & c \\
\hline .000 & .000 & .000 & .000 \\
\hline .003 & .01287 & .007 & -01087 \\
\hline .00525 & .01585 & .00975 & -.01305 \\
\hline . 00991 & .02074 & .01509 & -.01646 \\
\hline .02198 & .02964 & .02802 & -.02220 \\
\hline .04660 & .04264 & .05340 & -.0300 \\
\hline .07147 & .05261 & .07853 & -.03565 \\
\hline .09647 & .06077 & .10353 & -.04009 \\
\hline .14669 & .07348 & .15331 & -.04656 \\
\hline 19705 & .08279 & .20295 & -.05095 \\
\hline .24750 & .08941 & .25250 & -05361 \\
\hline .29800 & .09362 & .30200 & -.05474 \\
\hline .34852 & .09559 & .35148 & -.05439 \\
\hline .39905 & .09527 & .40095 & -.05243 \\
\hline .44955 & .09289 & .45045 & -.04909 \\
\hline .500 & .08871 & .50000 & -.04459 \\
\hline .55039 & .08298 & .54961 & -.03918 \\
\hline . 6007 & .07595 & .59930 & -.03311 \\
\hline .65093 & .06780 & .64907 & -.02660 \\
\hline . 70106 & .05877 & . 69894 & -.01989 \\
\hline .75109 & .04907 & .74891 & -.01327 \\
\hline .80102 & .03900 & .79898 & -.00716 \\
\hline 0 & .000 & & .000 \\
\hline
\end{tabular}

Figure 1. - NACA $63_{2}$ - A415 airfoil coordinates, $c=1.34 \mathrm{~m}$ (52.8 in.), $\mathrm{r}_{\mathrm{e}}=1.59 \%$.

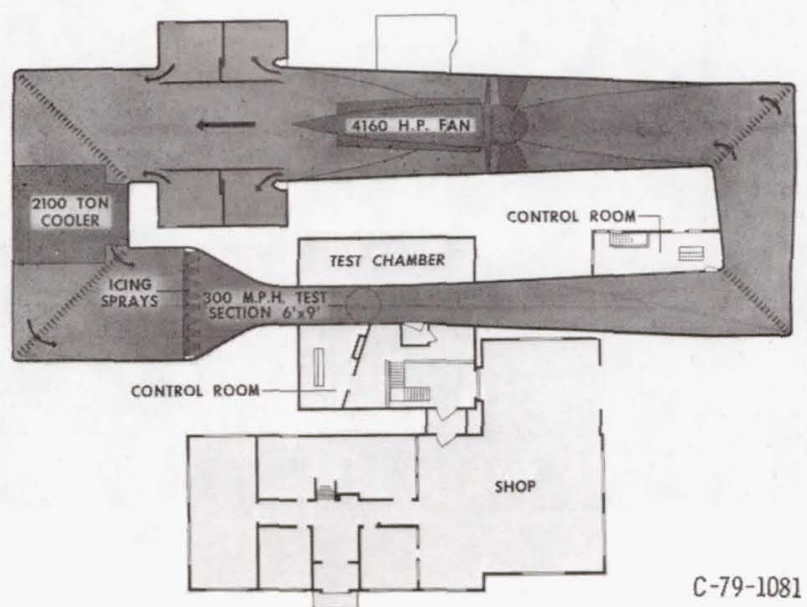

Figure 2. - NASA Icing Research Tunnel (IRT). 


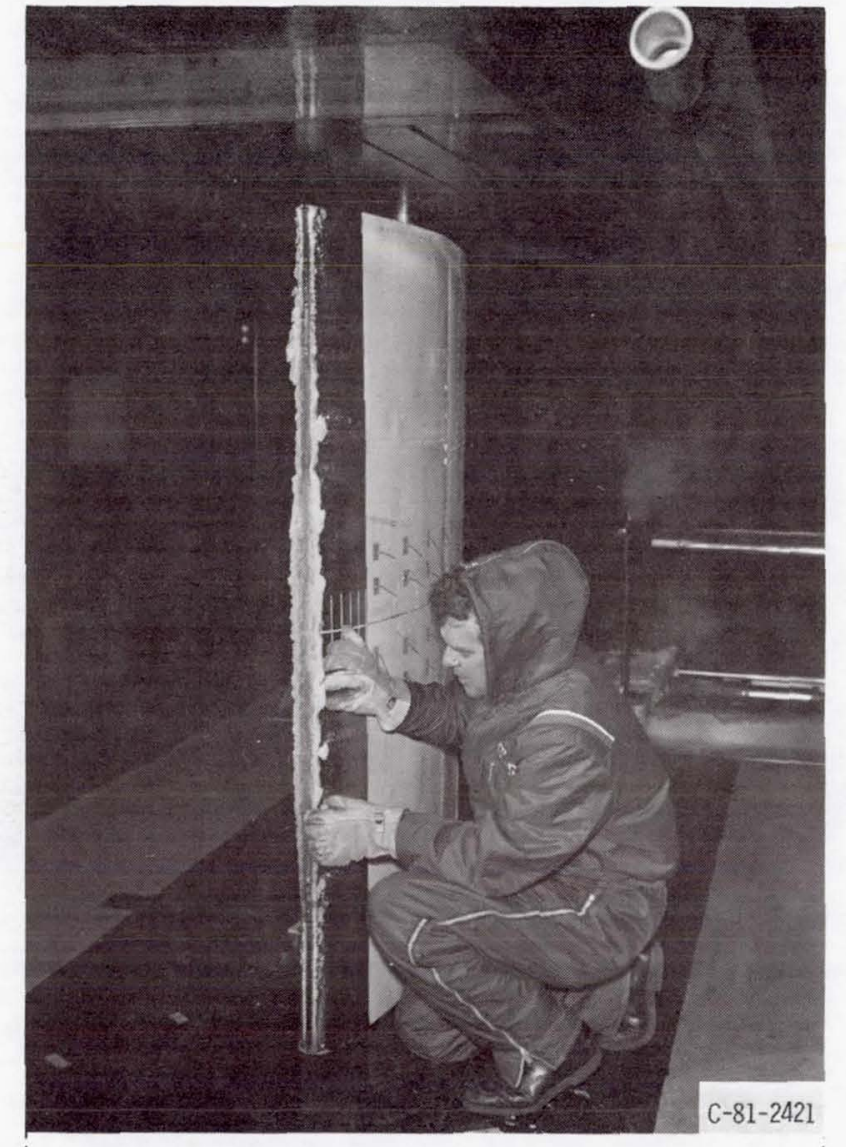

Figure 3. - NACA $63_{2}-\mathrm{A} 415$ wing section mounted in Icing Research Tunnel.

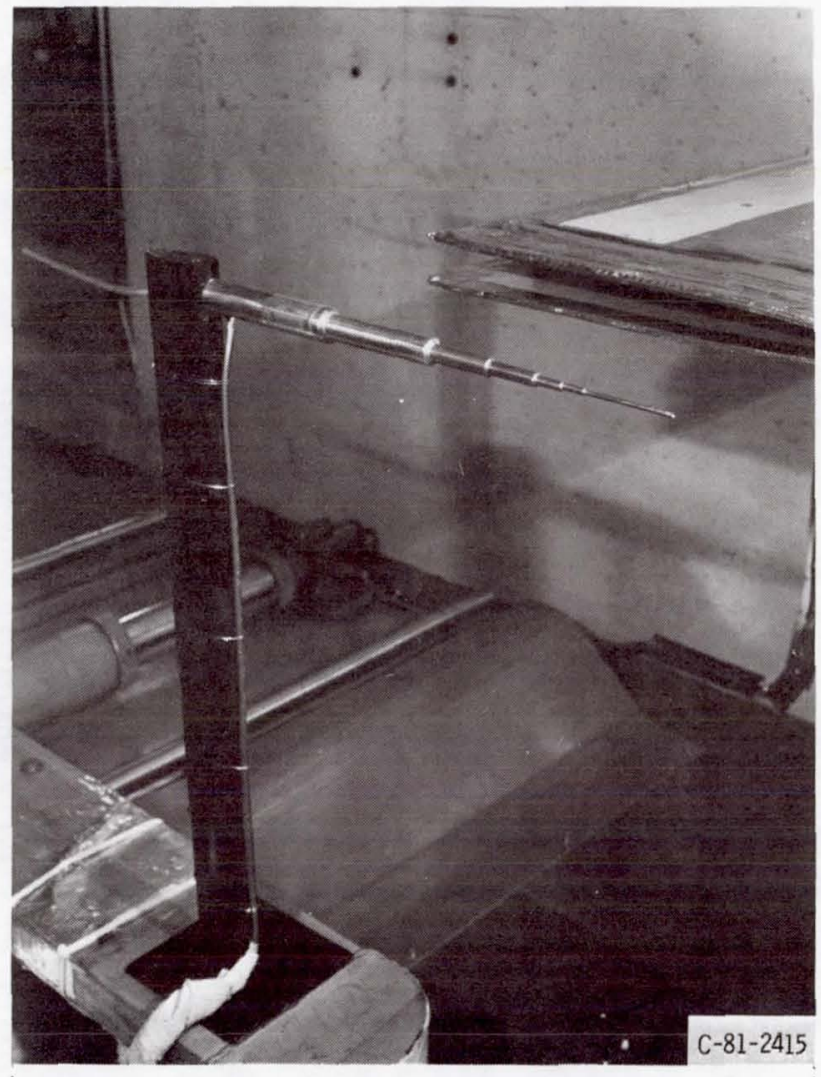

Figure 4. - Closeup of drag wake survey probe. 


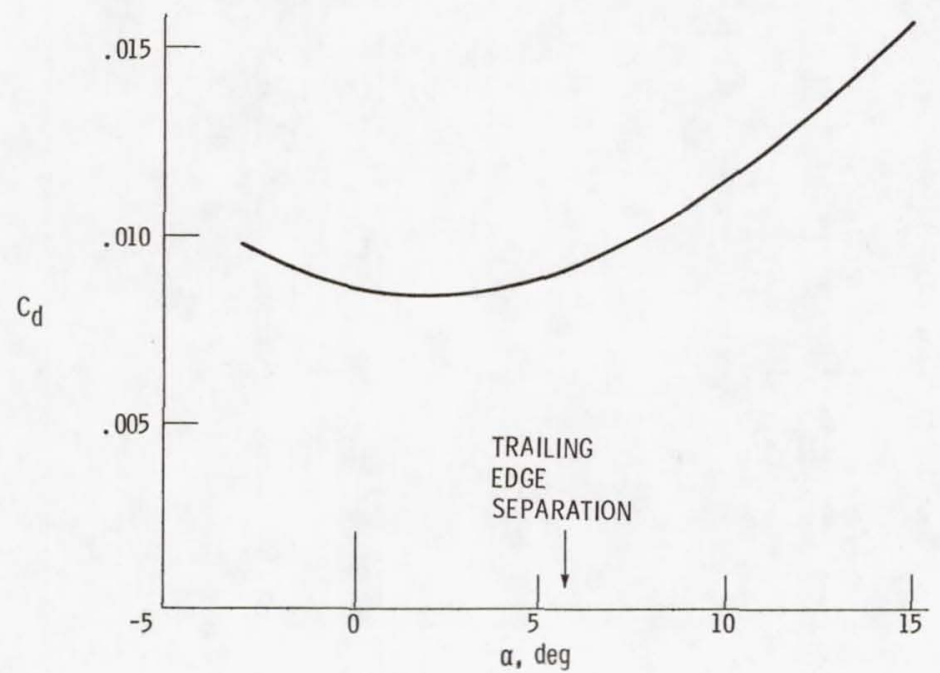

Fiqure 5. - Wing section drag polar.

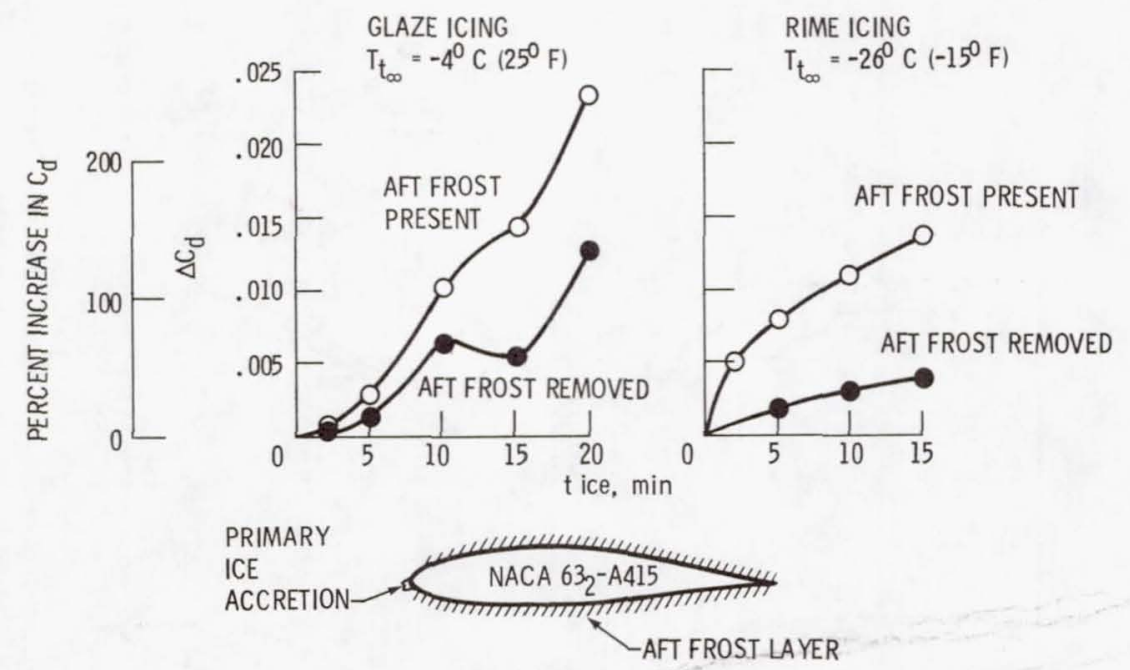

Figure 6. - Effect of aft frost growth for cruise conditions $V_{\infty}=5 / \mathrm{m} / \mathrm{sec}(115 \mathrm{mph})$, $\alpha=2.6^{0}, L W C=1.5 \mathrm{gm} / \mathrm{m}^{3}$. 


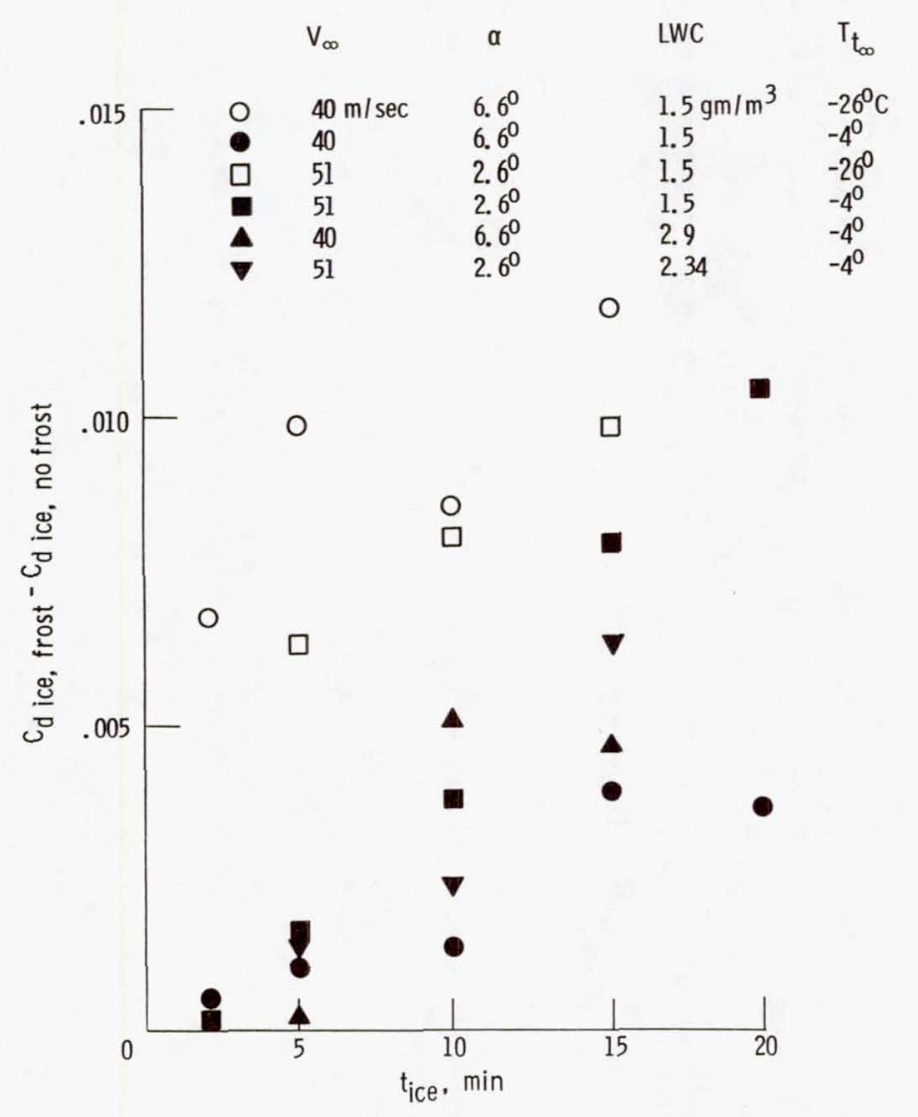

Figure 7. - Summary of aft frost effects.

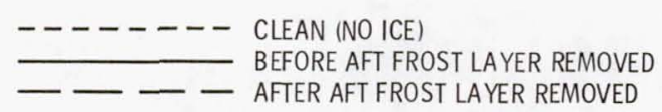

SUCTION SIDE PRESSURE SIDE
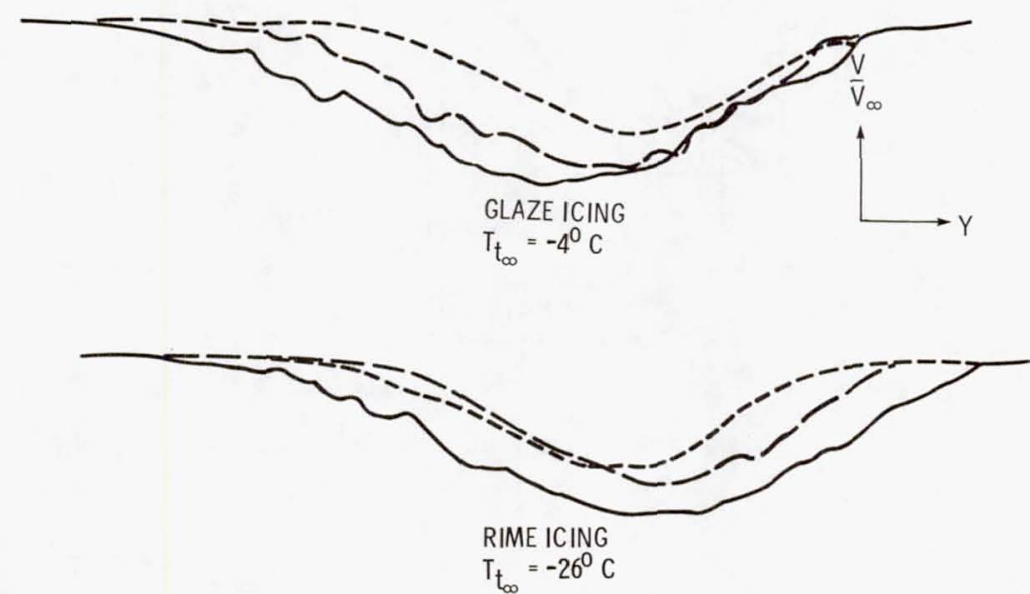

Figure 8. - Wake velocity profiles $V_{\infty}=5 / \mathrm{m} / \mathrm{sec}(115 \mathrm{mph}), \alpha=2.6^{0}, L W C=1.5 \mathrm{gm} / \mathrm{m}^{3}$, $t_{i c e}=10 \mathrm{~min}$. 


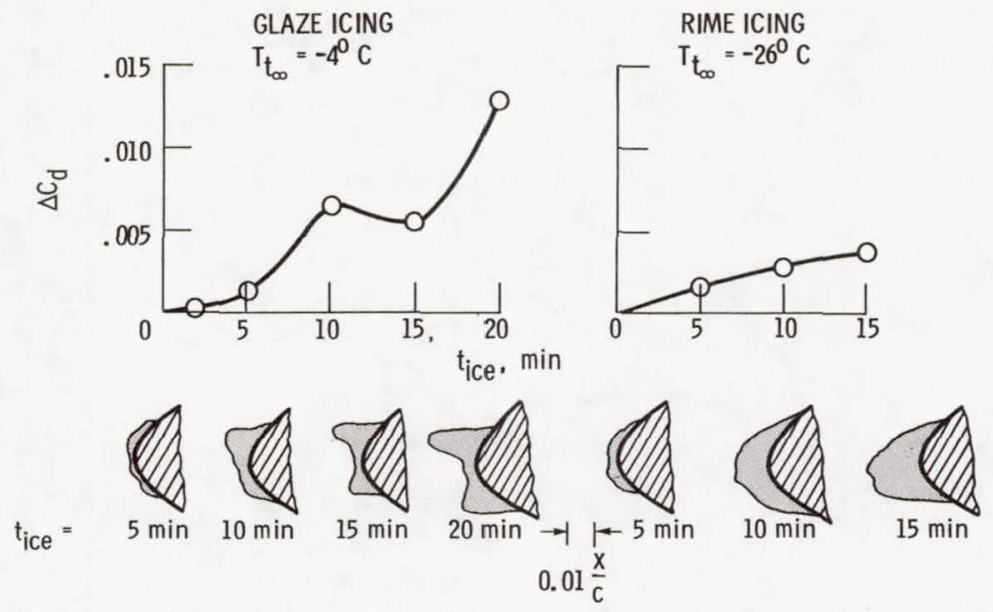

Figure 9. - Comparison of glaze and time icing for cruise conditions $V_{\infty}=5 / \mathrm{m} / \mathrm{sec}(115 \mathrm{mph})$, $\alpha=26^{0}, L W C=1.5 \mathrm{gm} / \mathrm{m}^{3}$.

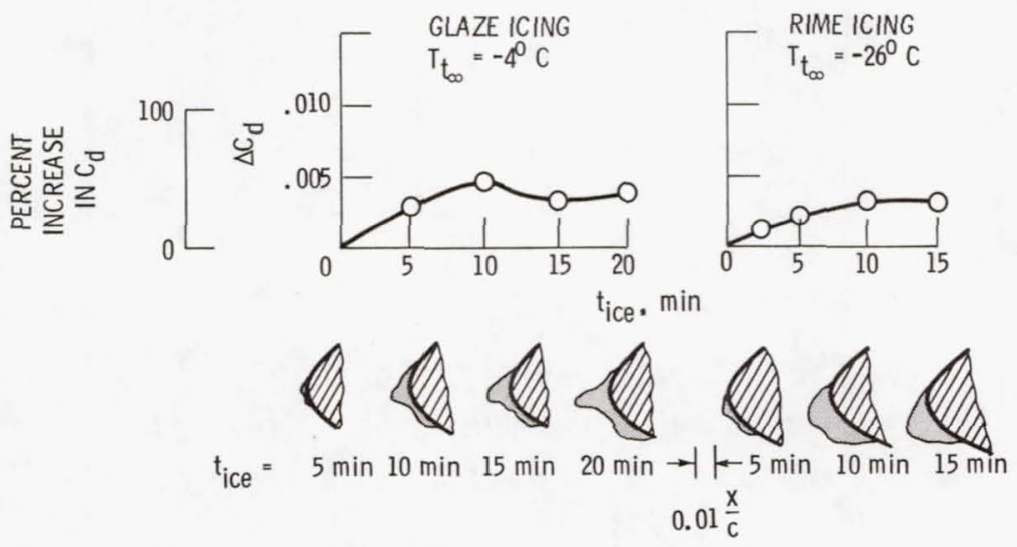

Figure 10. - Comparison of glaze and rime icing for climb conditions $\mathrm{V}_{\infty}=$ $40 \mathrm{~m} / \mathrm{sec}(90 \mathrm{mph}), \alpha=6.6^{\circ}, \mathrm{LWC}=1.5 \mathrm{gm} / \mathrm{m}^{3}$. 


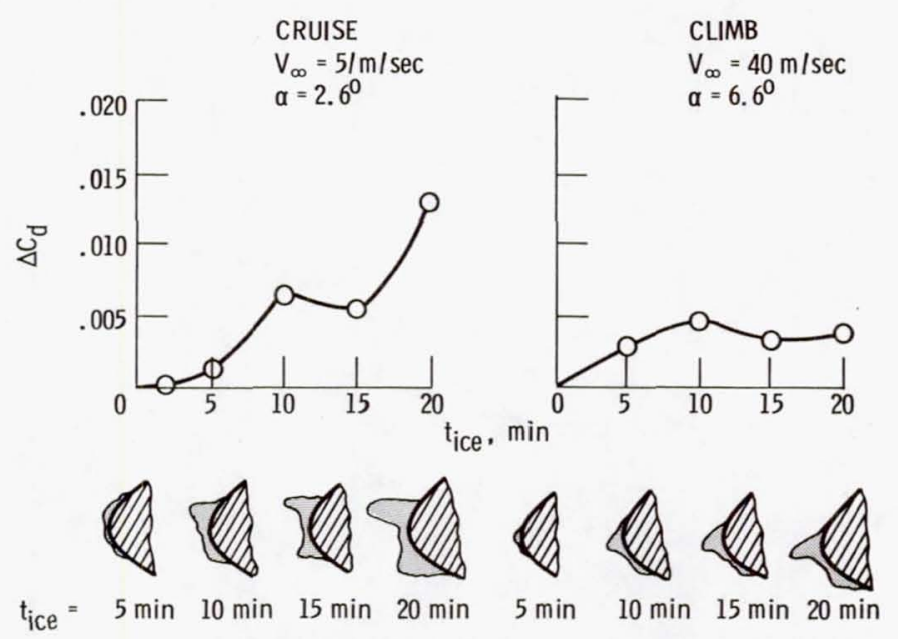

Figure 11. - Comparison of glaze icing for cruise and climb $L W C=1.5 \mathrm{gm} / \mathrm{m}^{3}$, $\mathrm{T}_{\mathrm{t}_{\infty}}=-4^{0} \mathrm{C}$.

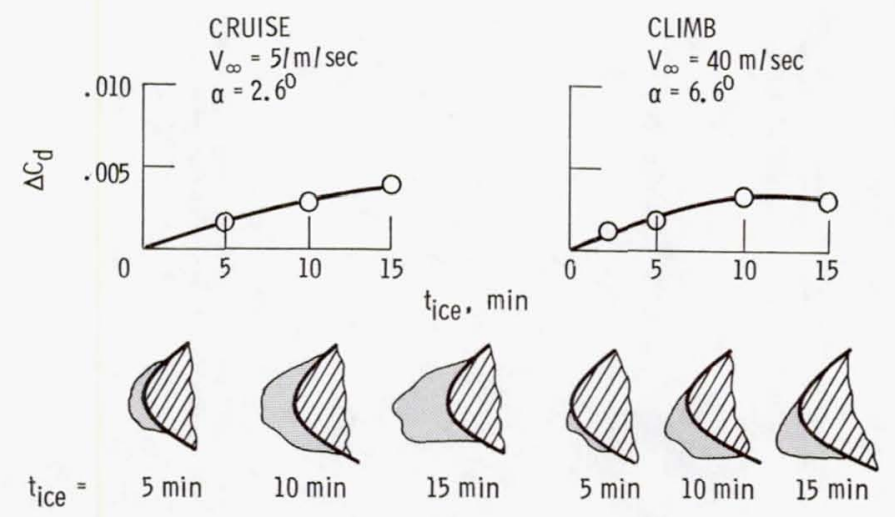

Figure 12. - Comparison of rime icing for cruise and climb $L W C=1.5 \mathrm{gm} / \mathrm{m}^{3}$, $\mathrm{T}_{\mathrm{t}_{\infty}}=-26^{0} \mathrm{C}$. 


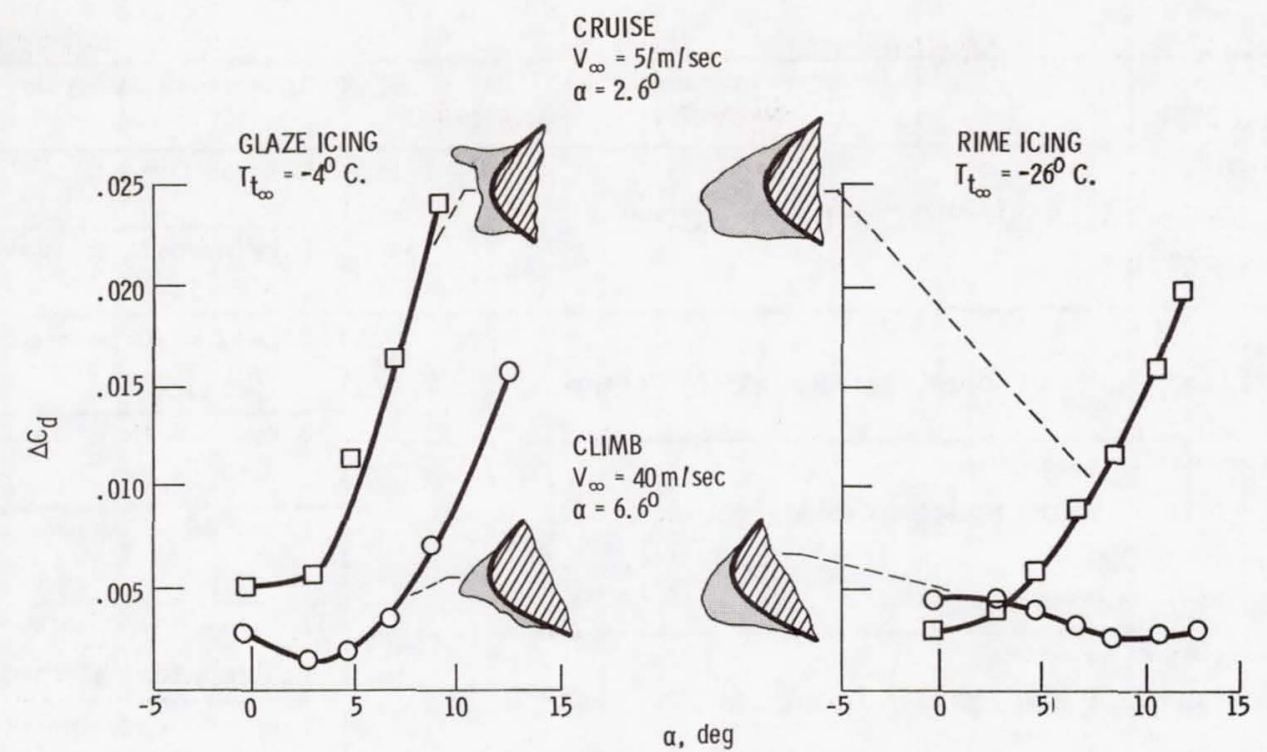

Figure 13. - Comparison of drag polars $L W C=1.5 \mathrm{gm} / \mathrm{m}^{3}, t_{\text {ice }}=15 \mathrm{~min}$.

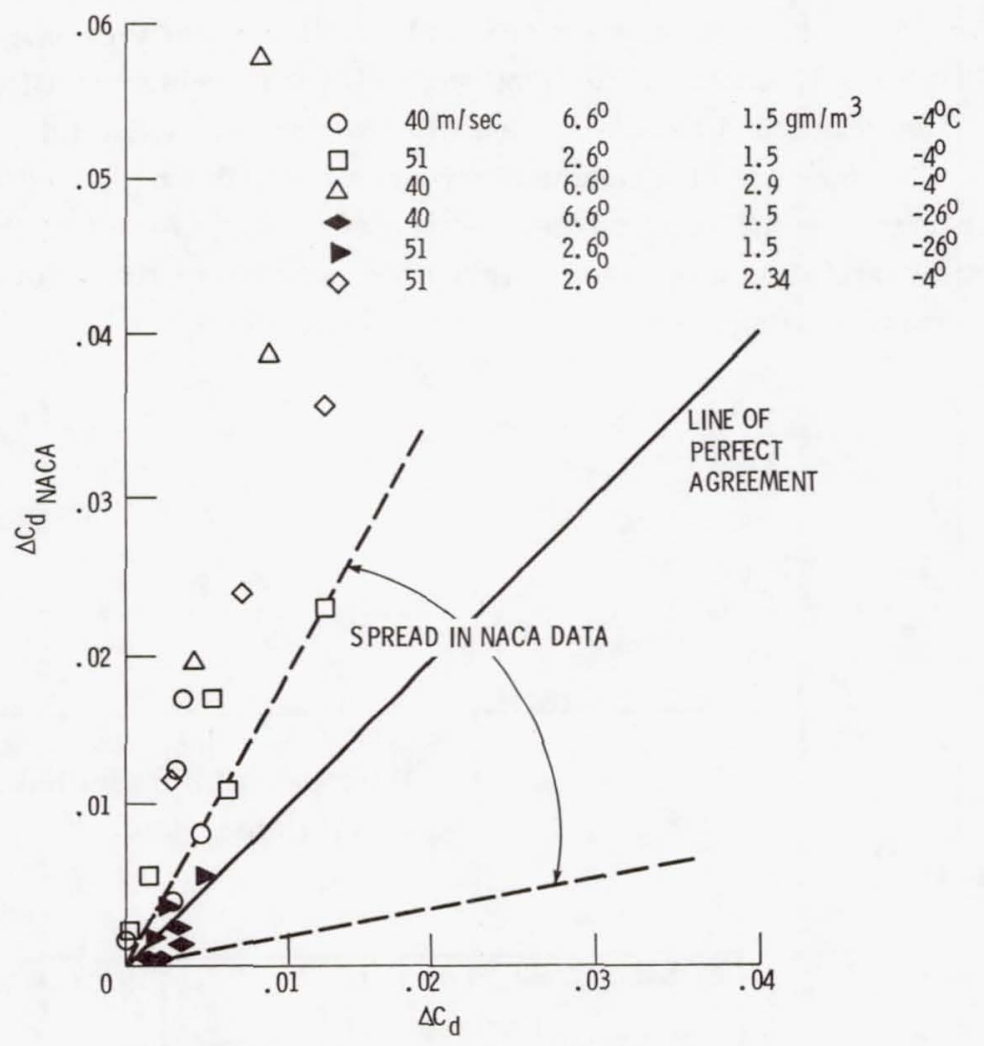

Figure 14. - Comparison of experimental results with NACA drag correlation. 


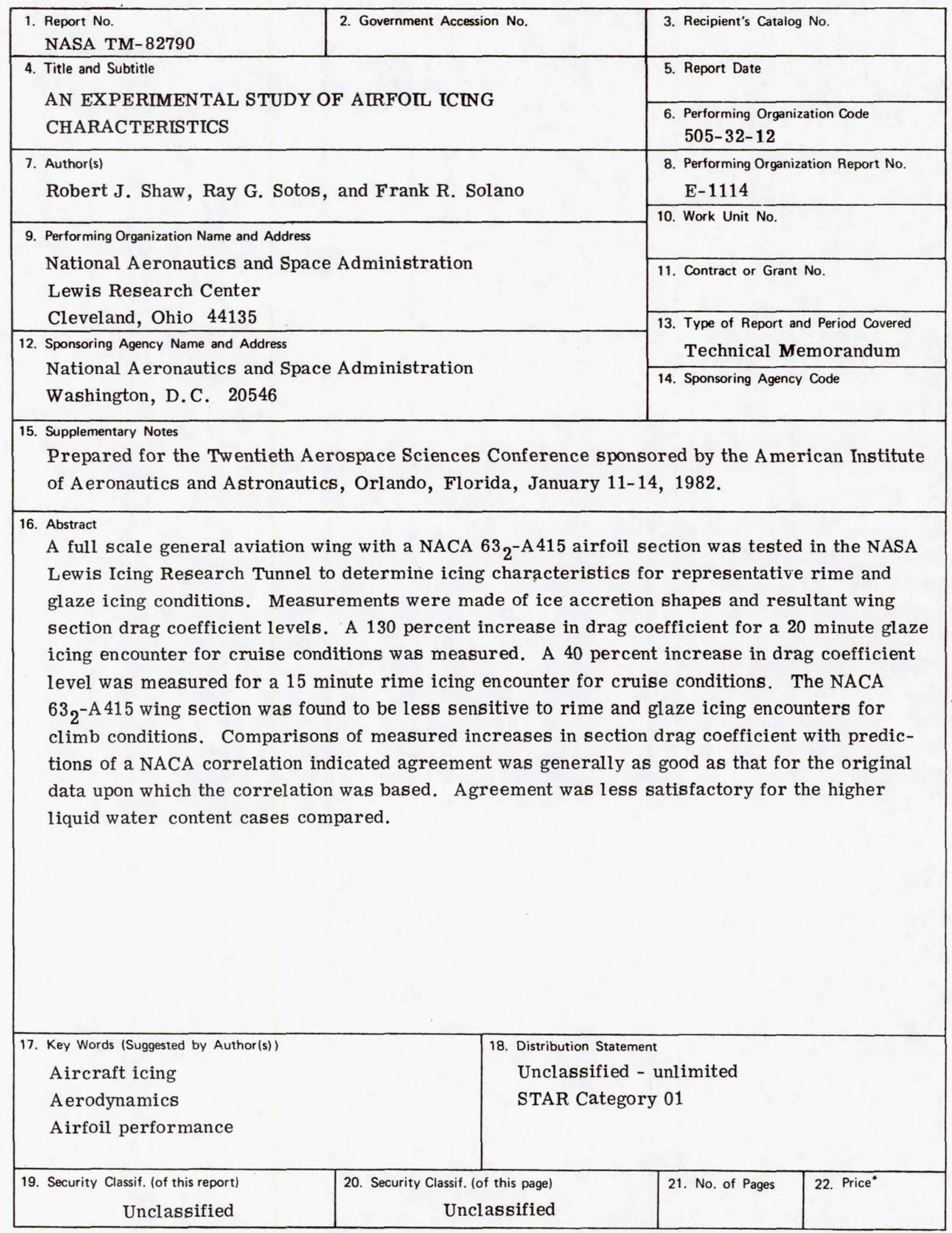

${ }^{*}$ For sale by the National Technical Information Service, Springfield, Virginia 22161 